\title{
THE REGULATION OF EXECUTIVE REMUNERATION IN SOUTH AFRICA
}

\author{
Vela Madlela \\ LLB LLM \\ Lecturer, Mercantile Law \\ University of South Africa (UNISA) \\ Palollo Michael Lehloenya \\ LLB LLM LLD \\ Senior Lecturer, Mercantile Law \\ University of South Africa (UNISA)
}

\section{SUMMARY}

Executive remuneration is one of the essential aspects of corporate governance that has attracted increasing attention in corporate circles and beyond in recent years. This comes in the wake of the global financial crisis of 2008 and the executive remuneration packages that are spiraling out of control. The increasingly excessive payments companies and financial institutions make to their management teams have given rise to growing consensus that executive remuneration needs to be controlled and regulated. Included among the identified causes of the problem are inter alia lack of transparency and accountability in determining executive remuneration, conflict of interests among those who determine executive remuneration, misalignment of management and shareholder interests, as well as inadequate protection of shareholder governance rights. The primary object of this paper is to examine the adequacy of the current regulatory framework in South Africa in addressing the challenges relating to executive remuneration. It further takes cognisance of the need for companies to achieve an appropriate balance between adequate regulation and the necessary flexibility in responding to the needs of different companies. The paper also makes proposals for reforming the current regulatory framework in a way that promotes fairness, transparency and accountability in executive remuneration.

\section{1}

\section{INTRODUCTION}

The question of how much company executives should be remunerated for their services to the company has become the focus of significant local and international attention in the years following the global financial crisis of $2008 .^{1}$ Concerns over excessive executive remuneration, the widening gap between the earnings of these executives and the rest of the workforce, as well as the effect that the exorbitant amounts paid has on stakeholder

Bradely "The Relationship between CEO and Company Performance in a South African Context" 20136 Journal of Economic and Financial Sciences 539540. 
interests have also provoked a debate over the kind of interventions required. ${ }^{2}$

Making the situation even more complex is the lack of consensus regarding the reasons that executive pay continues to rise and the extent of the problem. ${ }^{3}$ In South Africa, some of the perceived causes include lack of objectivity, transparency and accountability in determining such pay, conflict of interest among the decision-makers, misalignment of management and shareholder interests, inadequate protection of shareholder governance rights, as well as issues of unemployment and poor service delivery. ${ }^{4}$

One of the critical aspects in the on-going debate about executive remuneration is the method used to determine it. The responsibility to determine such remuneration is often left to the board of directors. In South Africa, as will be shown in this paper, the extent of the shareholders' influence in deciding the directors' remuneration is minimal. The requirement that companies must pay directors for the services they render to them subject to the shareholders' special resolution passed in a general meeting within the previous two years, ${ }^{5}$ is thus misleading to a large extent. The main challenge in situations where directors are left to determine their own pay, or that of top management is the ever-present risk of conflict of interests. ${ }^{6}$ Studies show that in the absence of alignment between the interests of top company executives and those of other stakeholders, the executives tend to advance their own interests as opposed to those of the company or other stakeholders. ${ }^{7}$

Despite considerable criticism in the media and academic circles, only a few companies in South Africa have taken steps to address the concerns relating to the rising executive pay. ${ }^{8}$ At least two factors have been attributed to the failure to act on the part of most South African companies. Firstly, there is an embedded sense of entitlement that has evolved among company executives over the years; and, secondly, there is lack of effective

2 PriceWaterhouseCoopers 'Executive Directors' Remuneration Practices and Trends Report" (July 2014) http://www.pwc.co.za/en_ZA/za/assets/pdf/executive-directorsremuneration-report-july-2014.pdf (accessed 2015-06-26) 1.

3 Ibid. See also Scholtz and Smit "Executive Remuneration and Company Performance for South African Companies Listed on the Alternative Exchange (AltX)" 2012 16(1) Southern African Business Review 2124.

4 PriceWaterhouseCoopers http://www.pwc.co.za/en_ZA/za/assets/pdf/executive-directorsremuneration-report-july-2014.pdf 1.

5 S 66(8) and (9) of the Companies Act 71 of 2008.

6 Ferrarini and Moloney "Executive Remuneration in the EU: The Context for Reform" 2002 21(2) Oxford Review of Economic Policy 304 309-310; and Sykes "Overcoming Poor Value Executive Remuneration: Resolving the Manifest Conflict of Interest" 2002 10(4) Corporate Governance 256257.

7 Scholtz and Smit 2012 16(1) Southern African Business Review 25.

8 A recent empirical study on remuneration packages of some of the major listed companies in South Africa conducted by Massie, Collier and Crotty has demonstrated that, despite growing public and shareholder scrutiny of executive remuneration in the country, executive cash and benefits packages have continued to increase, in some cases by between $155 \%$ and $423.5 \%$. See Massie, Collier and Crotty Executive Salaries in South Africa: Who should have a Say on Pay? (2014) 22-23. 
rules as well as serious repercussions for failing to abide by the relevant recommendations made in the King Reports on corporate governance. ${ }^{9}$

This article explores the adequacy of the existing South African regulatory framework in dealing with the challenges around executive remuneration, focusing mainly on the Companies Act, ${ }^{10}$ the King Report on Governance ("King III") and the JSE Listings Requirements.

\section{MEANING OF "REMUNERATION"}

Before proceeding to deal with the core issues covered in this paper, it is perhaps useful to define the concept of "remuneration" in relation to a company executive or director. Section 30 (6) of the Companies Act ${ }^{11}$ defines "remuneration" as including: the fees paid to a director for services rendered to or on behalf of the company; an amount paid to a person for accepting the office of director; salary, bonuses and performance-related payments; expense allowances to the extent that the director is not required to account for same; contributions paid under a pension scheme not otherwise required to be disclosed in terms of subsection (4)(b); the value of an option or right given to a past, current or future director or a person related to any of these persons; financial assistance provided to a past, present or future director or to a person related to any of them to subscribe for share options or securities or to purchase securities; in respect of a loan or other financial assistance by the company to a past, present or future director, any deferred, waived or forgiven interest, or the difference in value between the interest that would reasonably be charged in comparable circumstances at fair market rate in an arm's length transaction and the interest actually charged to the borrower if it is less.

The definition set out above is quite similar to the description given by the Greenbury Committee in the United Kingdom (UK) in respect of a typical executive remuneration package as far back as $1995 .{ }^{12}$ According to the Greenbury Committee, such a package includes base salary; benefits in kind; annual bonus; share options; other long-term incentive schemes; and pension rights. ${ }^{13}$

9 Crotty "Bigger Say on Pay is only a Starting Point" (10 August 2014) http://www.bdlive.co.za/opinion/2014/08/03/bigger-say-on-pay-is-only-a-starting-point (accessed 2015-06-26).

1071 of 2008.

11 lbid.

12 Report of a Study Group chaired by Sir Richard Greenbury "Directors' Remuneration" 1995 37.

13 Ibid. See also Hill "What Reward Have Ye? Disclosure of Director and Executive Remuneration in Australia" 199614 Company and Securities LJ 232 235; and Massie et al Executive Salaries in South Africa: Who should have a Say on Pay?2. 


\section{THE SOUTH AFRICAN REGULATORY FRAME- WORK}

In South Africa, executive remuneration is regulated through prescriptive laws such as the Companies $\mathrm{Act}^{14}$ and the common law, as well as through market-based regulatory instruments, including King III and the JSE Listings Requirements. ${ }^{15}$ In each instance, provision is made for the board of directors to assume the overall control of the remuneration-setting process.

Various regulatory mechanisms can play an important role in curbing excessive executive remuneration and in addressing the conflict of interests inherent in determining it. Principles of company law, such as the mandated remuneration disclosure under the Companies Act, ${ }^{16}$ the imposition of fiduciary duties on directors with the possibility of judicial enforcement and the oppression remedy can be of assistance. Other potentially useful tools promoted by the regulatory mechanisms include the use of independent non-executive directors, remuneration committees, giving shareholders a certain degree of control over the remuneration process, as well as the adoption of remuneration practices that seek to align the interests of management with those of shareholders. ${ }^{17}$ When used together, these tools can potentially be harnessed to address the existing problems in the area of executive remuneration in South Africa.

\section{Judicial review of executive remuneration}

Regulation of executive pay through the fiduciary duties of directors could be justified through the traditional conception of the company as a separate legal entity with the consequence that managerial and executive powers are exercised by the board of directors. Thus, directors owe fiduciary duties to the company in terms of both the Companies Act and the common law. ${ }^{18}$ The most important duties in this instance are the duty to act in good faith in the best interests of the company, to exercise powers for a proper purpose, to exercise an unfettered discretion in decision-making and to avoid a conflict of interests. ${ }^{19}$ Moreover, the directors must observe a certain degree of care, skill and diligence when exercising their powers and performing their functions. ${ }^{20} \mathrm{~A}$ breach of any of these duties will result in the directors being

\footnotetext{
71 of 2008.

The JSE Listings Requirements apply to companies whose shares are listed on the JSE.

71 of 2008.

For a discussion of strategies for controlling executive remuneration see Hill "Regulating Executive Remuneration: International Developments in the Post-scandal Era" 20063 European Company Law 64; Hill and Yablon "Corporate Governance and Executive Remuneration: Rediscovering Managerial Positional Conflict" 2002 25(2) University of New South Wales LJ 294 301-306; and Luiz "Executive Remuneration and Shareholder Voting" 201325 SA Merc LJ 267269.

18 The Companies Act has partially codified certain common law duties of directors. The common law principles will continue apply, except where they have been amended by the Companies Act. See Davis and Geach Companies and Other Business Structures in South Africa (2013) 115.

$19 \mathrm{~S} 76$ of 71 of 2008.

$20 \mathrm{~S} 76(3)(\mathrm{c})$ of 71 of 2008.
} 
liable to the company for any loss, damages or costs suffered by the company as a result. ${ }^{2}$

Judicial review of board decisions relating to executive remuneration is, therefore, possible since company shareholders and stakeholders may, in principle, challenge excessive executive remuneration by way of a statutory derivative action introduced by section 165 of the Companies Act. ${ }^{22}$ The availability of this remedy should, in theory, deter company directors from overpaying themselves at the expense of their companies. It should also encourage the accountability of directors to shareholders and other stakeholders. The use of statutory derivative action to enforce the directors' duties to the company can also play a role in aligning the interests of management with those of the shareholders. ${ }^{23}$

At the same time, it is possible for shareholders to challenge excessive executive remuneration in a court of law by invoking the remedy against oppressive or unfairly prejudicial conduct provided for in section 163 of the Companies Act. ${ }^{24}$ The courts have wide powers under this provision to grant interim or final relief, including inter alia an order: restraining the conduct complained of, regulating the company's affairs, directing the company to amend its Memorandum of Incorporation or to create or amend a unanimous shareholder agreement, directing an issue or exchange of shares, appointing replacement, or additional directors, or declaring any person delinquent or under probation, varying or setting aside a transaction to which the company is a party and compensating the company or any other party to the transaction or agreement, directing rectification of the registers or other records of a company, and for the trial of any issue as determined by the court.

Notwithstanding the existence of the abovementioned remedies, judicial review of executive remuneration has so far not proved to be an effective deterrent to excessive executive pay. There is yet to be a single court case in South Africa addressing the issue even as executive salaries continue to

$21 S 77(2)$ of 71 of 2008 . For a breach of the fiduciary duties, directors may be held liable in accordance with the common law principles relating to breach of fiduciary duty. For a breach of the duty of care, skill and diligence, directors may be held liable in accordance with the common law principles of delict. For the purposes of liability of directors in terms of this statutory provision the term director is extended to include an alternate director, a prescribed officer and a member of a board committee.

22 S 165 of 71 of 2008 has introduced a statutory derivative action in South African company law. Shareholders must apply to court for leave to pursue the action.

23 For a discussion of the rationale for the derivative action and its role in corporate governance, see Cassim "Costs Orders, Obstacles and Barriers to the Derivative Action under Section 165 of the Companies Act 71 of 2008 (Part 1)" 201426 SA Merc LJ 12-4.

24 In terms of s 163(1) of 71 of 2008 a shareholder or a director may apply to court if inter alia any act or omission of the company or a related person has had a result that is oppressive or unfairly prejudicial to, or that unfairly disregards the interests of the applicant; or if the powers of a director or prescribed officer or a person related to the company are being or have been exercised in a manner that is oppressive or unfairly prejudicial to, or that unfairly disregards the interests of the applicant. In terms of s 2(1) a person related to the company is one who directly or indirectly controls the company or its business. 
soar. ${ }^{25}$ The most probable reasons for this are the challenges prospective complainants are likely to face in the early stages of a statutory derivative action. Some of these challenges include the costs involved, lack of access to internal information and the operation of the rebuttable presumption that the decision not to sue the errant directors is in the best interests of the company. ${ }^{26}$ In addition, the courts themselves have traditionally shown reluctance to interfere or voice an opinion on matters relating to executive remuneration. ${ }^{27}$ Instead, the courts have generally preferred to leave decisions on executive remuneration to the company itself to deal with internally. ${ }^{28}$

Some commentators have voiced support for the "hands-off" approach adopted by the courts regarding regulation of executive remuneration. ${ }^{29}$ This is based on, among other things, the fact that the courts lack expertise in this highly specialized area, and there are very few guidelines for them to rely on. ${ }^{30}$ Executive remuneration may also vary significantly in different companies, depending on the type of industry as well as the extent of the need to attract, incentivise or retain suitable talent. ${ }^{31}$ South African company law has also recently adopted the business judgment rule, which is likely to extend further protection to company boards against judicial scrutiny in cases of excessive remuneration. ${ }^{32}$

\section{Independent non-executive directors and remuneration committees}

The existing problems relating to executive remuneration have, in part, been attributed to the lack of effective arms-length negotiation in the remuneration setting process. ${ }^{33}$ The independence and accountability of the Board can be compromised in a number of ways, including having a dominant CEO on the board, lacking a sufficient number of robust and independent-minded nonexecutive directors, and having majority shareholders who use their power to monitor and control management. Conflicted company boards may, in turn,

25 See Massie et al Executive Salaries in South Africa: Who should have a Say on Pay? 2223; and Collier, Idensohn and Adkins "Income Inequality and Executive Remuneration: Assessing the Role of Law and Policy in the Pursuit of Equality" 2010 34(2) South African Journal of Labour Relations 8494.

26 Cassim 201426 SA Merc LJ 1-23; Cassim "Obstacles and Barriers to the Derivative Action: Costs Orders under Section 165 of the Companies Act of 2008 (Part 2)" 201426 SA Merc LJ 228-246; Cassim "When Companies are Harmed by their Own Directors: The Defects in the Statutory Derivative Action and the Cures (Part 1)" 201325 SA Merc LJ 168-183; and Cassim "When Companies are Harmed by their own Directors: The Defects in the Statutory Derivative Action and the Cures (Part 2)" 201325 SA Merc LJ 301-322.

27 Hill 199614 Company and Securities LJ 233; and Randall and Kenneth "Litigating Challenges to Executive Pay: An Exercise in Futility" 200179 Washington University Law Quarterly 569 570-571.

28 Ibid.

29 Hill 199614 Company and Securities LJ 233.

30 Ibid.

lbid.

2 See s 76(4) of the Companies Act 71 of 2008.

33 Bebchuk and Fried "Pay Without Performance: Overview of the Issues" in Kieff and Paredes (eds) Perspectives on Corporate Governance (2010) 119. 
compromise the independence of the remuneration-setting process. Appointing non-executive directors who are independent from executive management and controlling shareholders to the board may be one of the answers to strengthening board independence and accountability. ${ }^{34}$ Independent non-executive directors help to protect the interests of minority shareholders and other stakeholders through effective monitoring and having no vested interests in board decisions. ${ }^{35}$ In addition to independent directors, independent remuneration committees can also be established to counter the influence of management by ensuring that executive remuneration is determined objectively. ${ }^{36}$

However, in South Africa there are no mandatory rules regulating board independence. Apart from the fiduciary duties of directors, there is insufficient guidance in the Companies Act on the definition of independence. There are also no mandatory rules requiring companies to establish independent remuneration committees. ${ }^{37}$ Under the Companies Act, the board of directors may appoint any number of board committees and delegate to a committee any of the powers of the board. ${ }^{38}$ In practice, South African companies do establish remuneration committees and they often owe their existence and derive their mandate from the board of directors. ${ }^{39}$ The question is whether these committees can be fully independent and effective.

The independence of both the board of directors and the remuneration committees is mainly regulated by voluntary and non-binding best practice principles contained in King III. ${ }^{40}$ King III specifically calls for the creation of remuneration committees consisting of non-executive directors, a majority of whom should be independent and whose role should be to determine and

34 Gordon "Say on Pay: Cautionary Notes on the UK Experience and the Case for Muddling Through" in Kieff and Paredes (eds) Perspectives on Corporate Governance (2010) 190.

35 The appointment of independent non-executive directors has been a dominant theme of European responses to executive remuneration. See Hill 20063 European Company Law 64.

36 See Hill 20063 European Company Law 64; Hill and Yablon 2002 University of New South Wales LJ 301-306; and Luiz 201325 SA Merc LJ 269.

37 S 952 the Dodd-Frank Wall Street Reform and Consumer Protection Act introduced a new s $10 \mathrm{C}$ in the Securities Exchange Act of 1934 (15 U.S.C. 78a et seq) which provides for the membership and independence of the compensation committee in the USA. There are no similar provisions in the corporate legislation of other jurisdictions, such as the United Kingdom, Australia and South Africa.

$38 \mathrm{~S} 72(1)$ of 71 of 2008 . However, the board of directors remains responsible for the proper performance of its duties despite the delegation of the duty to a committee. See Davis and Geach Companies and Other Business Structures in South Africa 142-143.

39 Institute of Directors in Southern Africa "Remuneration Committee Forum: Position Paper 1" (May 2013) http://www.ey.com/Publication/vwLUAssets/Remueration_Committee_Forum/ \$FILE/Position_Paper_1_A_framework_for_remuneration_committees.ponf (accessed 201506-29) 5.

40 Principle 2.1.8 of King III recommends that there should be a balance of power in company boards, with a majority of directors being non-executive directors. The majority of nonexecutive directors should be independent. Furthermore, principle 2.16 of King III recommends that the chairman of the board should be an independent non-executive director and that the role of the independent non-executive chairman should be kept separate from that of the CEO. 
monitor executive remuneration. ${ }^{41}$ The JSE Listings Requirements also compel all listed companies to appoint a remuneration committee in line with King III. The composition of such a committee, a brief description of its mandate, the number of meetings it is required to hold and other relevant information, must be disclosed. ${ }^{42}$ According to King III, remuneration committees should assist the company boards in setting and administering remuneration policies. ${ }^{43}$ The remuneration committees should make recommendations to the board of directors on specific remuneration packages for each executive director and on the fees to be paid to each nonexecutive director. They should also evaluate the performance-related aspects of individual directors' remuneration. ${ }^{44}$

The effectiveness of remuneration committees comprised of independent directors has, however, been questioned by some scholars. ${ }^{45}$ They are of the view that the ability of independent non-executive directors to effectively monitor executive remuneration may be constrained by a number of economic, social and psychological factors which tend to operate in favour of executive management. ${ }^{46}$ These factors include inter alia the power of executive management to determine the remuneration of the non-executive directors; feelings of friendship, loyalty, collegiality, cognitive dissonance and solidarity between the various directors; time constraints; as well as the lack of requisite expertise amongst members of the remuneration committee. ${ }^{47}$ In addition, the shareholding of independent non-executive directors in most companies is insignificant, which gives them little financial incentive to monitor executive remuneration effectively. ${ }^{48}$

It is clear from the above discussion that independent non-executive directors and remuneration committees have their own limitations and cannot be a complete solution to the problems around executive remuneration. Other remedial alternatives may, therefore, be required. One such alternative is hiring external remuneration experts. However, the independence of outside remuneration consultants themselves has been questioned. ${ }^{49}$ The basis of these questions is that conflict of interests is inevitable in instances where the remuneration consultants are hired by the executive management or where remuneration consultants perform other services for the company, as is the case with most audit firms. It is submitted, therefore, that remuneration consultants should be appointed by the remuneration committee, and the committee should satisfy itself that the

\footnotetext{
See Principles 2.23.6; 2.23.7; and 2.25.2 of King III.

S 7.F.6(d) of the JSE Listings Requirements.

Principle 2.25.2 of King III.

44 See Davis and Geach Companies and Other Business Structures in South Africa 144.

45 See Mongalo "Shareholder Activisim in the United Kingdom Highlights the Failure of Remuneration Committees: Lessons for South Africa" 2003120 SALJ 756; Luiz "An Appropriate Regime for the Remuneration of Executives" XXXXIX CILSA 57 67-69; and Hill 199614 Company and Securities LJ 235.

46 Hill 199614 Company and Securities LJ 235.

47 Bebchuk and Fried in Kieff and Paredes (eds) Perspectives on Corporate Governance 115130.

48 Bebchuk and Fried in Kieff and Paredes (eds) Perspectives on Corporate Governance 128129.

49 Gordon in Kieff and Paredes (eds) Perspectives on Corporate Governance 196. See also Luiz XXXXIX CILSA 69.
} 
consultants are truly independent of the company. Independent remuneration committees can further be supplemented by measures such as enhanced remuneration disclosure and the strengthening of directors' accountability to shareholders, increased consultations with shareholders and stakeholders, as well as allowing shareholders to vote on some board decisions relating to executive remuneration.

\section{Disclosure}

Full disclosure in so far as executive remuneration is concerned constitutes an important regulatory tool in that the availability of accurate information enhances transparency and accountability. These, in turn, allow shareholders and other stakeholders to monitor the board's decisions and practices concerning executive pay more effectively. This section examines the disclosure requirements that currently apply to executive remuneration in terms of the Companies Act, King III and the JSE Listings Requirements. It explores the extent to which these requirements are adequate and whether they effectively address the problems relating to remuneration policies and practices.

\section{The Companies Act 71 of 2008}

The provisions of the Companies Act require full disclosure of directors' remuneration in the company's annual financial statements with a view to keeping the shareholders and other stakeholders informed. Section 30(6) provides for a rather wide definition of "remuneration" and outlines an extensive list of benefits that must be disclosed should they be extended to a director. ${ }^{50}$ Section 30(4) further requires a separate disclosure of the following information in the audited annual financial statements: the remuneration and benefits received by each director or prescribed officer; the amount of pensions payable to current or past directors or prescribed officers; payments to a pension scheme with respect to current or past directors or prescribed officers; compensation for loss of office with respect to current or past directors or prescribed officers; any securities issued and the consideration received by the company for those securities; and the details of service contracts of current or past directors or prescribed officers of the company.

The annual financial statements must also disclose the remuneration and benefits in respect of services rendered as director or prescribed officer of the reporting company, or services rendered while a director of any other company within the same group of companies. ${ }^{51}$

50 See the list under the sub-heading "Meaning of remuneration" above.

51 S 30(5) of the Companies Act 71 of 2008. 


\section{King III}

King III recommends that each company should disclose the remuneration of each individual director and certain senior executives in its remuneration report contained in the annual integrated report. ${ }^{52}$ The company's remuneration report should include the following: all benefits paid to directors; the salaries of the three most highly-paid employees who are not directors; the policy on base pay; participation in share incentive schemes; the use of benchmarks; incentive schemes to encourage retention; justification of salaries above the median; material payments that are exgratia in nature; policies regarding executive employment; and the maximum expected potential dilution as a result of incentive awards. ${ }^{53}$ In addition, King III recommends that companies should adopt remuneration policies that are in alignment with the company's strategy and linked to individual performance. In terms of Principle 2.25.3, the remuneration policy should address base pay and bonuses, employee contracts, severance and retirement benefits, as well as share-based and other long-term incentive schemes.

\section{The JSE listings requirements}

The JSE Listings Requirements have expressly adopted the recommendations made in King III. In terms of the JSE Listings Requirements, each listed company is required to apply the principles set out in King III on a "comply-or-explain" basis. ${ }^{54}$ Moreover, listed companies are required to disclose each director's remuneration for the current and preceding financial year, whether receivable as a director or in any other capacity. They must specifically disclose the following information: an analysis in aggregate and by director of remuneration and benefits paid for the current financial year and the preceding financial year, distinguishing separately between executive and non-executive directors, fees for services as director; management, consulting, technical or other fees; basic salary; bonuses and performance-related payments; sums paid by way of expense allowance; any other material benefits received; contributions to pension schemes; any commission, gain or profit-sharing arrangements; and details of share options or any other right given.

\footnotetext{
Principle 2.26 of King III.

Ibid.

54 Companies that intend to list their shares on the JSE are required to comply with this disclosure requirement before their shares can be listed on the JSE in terms of S 7.F.5(a) and (b) of the JSE Listings Requirements. Listed companies are further required to provide a statement showing the extent of their compliance with King III. Where King III is not complied with, companies are required to state the reasons for their non-compliance. See s 8.63(a)(i) and (ii) of the JSE Listings Requirements.
} 


\section{Assessment of South Africa's remuneration disclosure regime}

From the preceding overview of South Africa's current remuneration disclosure regime, it is quite clear that section 30(4) and (5) of the Companies Act comprise an improvement on section 297 of the Companies Act 61 of 1973, which merely required that a company's financial statements disclose emoluments payable to executive directors as an aggregate. In contrast, section 30(4) and (5) of the current Companies Act call for separate disclosure of the nature and extent of various constituent parts of each director's or prescribed officer's remuneration package.

Requiring separate disclosure in respect of different components of executive remuneration packages will enable the stakeholders to assess whether the composition of these packages has been carefully considered and structured, as well as whether an appropriate balance is being maintained between fixed remuneration, short-term components and longterm components. The requirement will also facilitate effective comparison between various companies regarding payments made to their executives. The effect of the comprehensive definition of remuneration given under the Companies Act has been to widen South Africa's disclosure regime in respect of executive remuneration quite considerably.

Despite the effort made in the Companies Act to ensure that the shareholders and other stakeholders are given a clearer and better insight into the composition of executive remuneration, the Companies Act has inadequately addressed some important disclosure-related aspects of performance-based remuneration. An example of this is the fact that the Companies Act imposes no obligation on companies to disclose the key performance conditions against which directors' and prescribed officers' conduct is measured. This contrasts with the approach adopted by King III, which is to require companies to describe the basis on which executive remuneration is determined. The failure to impose stringent performance conditions on directors can lead to unpalatable consequences where performance-based incentives, such as bonuses and share options end up being abused.

Unlike equivalent legislation in countries such as the UK and Australia, the Companies Act does not require disclosure of a company's remuneration policy, nor how such policy was applied in previous years. ${ }^{55}$ King III, on the contrary, makes it clear that a remuneration policy should address the appropriate division between base pay and performance-related components of remuneration. It further recommends that aspects such as service contracts, severance and retirement benefits, the extent and rationale for annual bonuses, as well as share-based and other long-term

55 S $300 A(1)(a)$ of the Australian Corporations Act 2001 (Cth) requires companies to disclose the policy on the nature and amount of directors' remuneration. In the UK, 421(2A) of the Companies Act 2006, inserted by s 79(4) of the Enterprise and Regulatory Reform Act 2013, requires a separate disclosure of a future directors' remuneration policy. See s 25-40 of the 2013 Regulations for the prescribed contents of a future directors' remuneration policy. 
incentive schemes, should be considered in such policy. ${ }^{56}$ Of course, the contents of King III are only recommendations and, as such, not binding.

\section{Shareholder monitoring}

The monitoring role of independent remuneration committees as part of the effort to curtail excessive executive remuneration can be supplemented by action from shareholders themselves. Shareholder monitoring may be exercised through their power to replace directors in the case of inappropriate pay decisions, as well as through voting on remuneration reports, remuneration policies, share-based schemes and the actual remuneration packages recommended by company boards. Shareholder monitoring can also take less direct forms, such as engagement. Shareholders, however, need to be supported by timeous, accurate and comprehensive disclosure in order to be effective in this role. This section examines the extent to which the existing regulatory mechanisms in South Africa promote and support shareholder monitoring of executive pay.

\section{The Companies Act 71 of 2008}

The extent of the shareholders' influence over the remuneration policies and practices of companies is limited under the current Companies Act. Although companies are required to include details relating to director and executive remuneration in their audited annual financial statements presented at their annual general meetings, ${ }^{57}$ and shareholders get the opportunity to engage with their boards on the contents during these meetings, in reality this kind of engagement adds little value as it only takes place after the company has (already) paid the directors and executives for the preceding financial year. If anything, the engagement is likely to achieve a commitment to adopt better remuneration practices in future.

Furthermore, unlike equivalent legislation in countries such as the UK and Australia, the Companies Act does not make provision for shareholders to approve a company's remuneration report, nor does it require companies to disclose their remuneration policies. ${ }^{58}$ Consequently, there is no requirement in the Companies Act that the remuneration policy should be put to shareholder vote. ${ }^{59}$ The Companies Act also makes no requirement that

\footnotetext{
See Principle 2.25.4 of King III.

S 30 (4) to (6) and s 61 (8)(a)(ii) of 71 of 2008.

58 See s 439 of the Companies Act 2006 which gives shareholders of a UK quoted company an annual advisory vote on a resolution to approve the directors' implementation report at the accounts meeting. S 250R(2), read with s 250R(3) of the Australian Corporations Act 2001 (Cth) gives shareholders a non-binding advisory vote on the remuneration report. However, in terms of s 250V the Australian Corporations Act 2001 (Cth), if at least a 25\% vote is passed against the resolution to adopt the remuneration report at two consecutive annual general meetings, a separate resolution will be triggered for the re-election of all the elected directors who have signed the remuneration report within 90 days. This ensures that companies take into account shareholders' concerns.

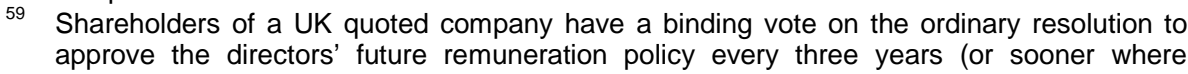
changes to the policy are made). See 439A, read with s 421(2A) of the Companies Act 2006.
} 
elements of executive remuneration, such as termination packages must be subject to shareholder approval. This is in sharp contrast to the approach followed in the USA and the UK, in terms of where legislation provides for disclosure and shareholder vote on termination payments. ${ }^{60}$ In the absence of these requirements, there is little that can stop company boards from paying exorbitant and often controversial salaries and termination packages to their executives, despite poor performance.

The Companies Act also has no equivalent provision to section 227 of the old Companies Act. ${ }^{61}$ This provision prohibited payments or granting of benefits or advantages to directors for loss of office or in connection with arrangements and take-over schemes, unless the full particulars regarding the proposed payment, or benefit, or advantage, have been disclosed to members of the company and have been approved by a special resolution. ${ }^{62}$ This gave the shareholders some form of control over the termination packages payable to senior executives. ${ }^{63}$

The requirement in section 66(9) of the Companies Act that a company may only pay its directors for services rendered provided that such remuneration is approved by the shareholders through a special resolution, passed within the previous two years, is also quite controversial and inept. It is not clear what is meant by "remuneration" since the term is not defined in that provision, nor in section 1 of the Companies Act. The term is only defined in section $30(6)$ in relation to information that must be disclosed in the annual financial statements.

It is, therefore, uncertain whether shareholder approval of directors' remuneration is required only in respect of services rendered as directors, or whether the same requirement applies to services directors render as company executives. ${ }^{64}$ It is submitted that the latter is precisely the area in which stringent shareholder control is required.

It is regrettable that the requirement of shareholder approval does not apply to remuneration of executives who are not members of the board, nor to share ownership schemes. The requirement of shareholder approval is thus very limited in scope, which in practice often leads to companies seeking only shareholder approval in respect of fees paid to non-executive directors. The often problematic remuneration of senior executives ends up

60 In the USA such disclosure and shareholder approval are provided for in s 951 of the DoddFrank Wall Street Reform and Consumer Protection Act, which introduced a new s 14A in the Securities Exchange Act of 1934 (15 U.S.C. 78a et seq.) In the UK, the relevant statute is the Enterprise and Regulatory Reform Act 2013 which imposed new restrictions on directors' remuneration and termination payments by inserting the new Chapter 4A of the Companies Act 2006.

61 This provision dealt with payments to directors for loss of office or in connection with arrangements and take-over schemes.

$62 \mathrm{~S} 227(1)(\mathrm{a})$ of 61 of 1973.

63 Luiz has, however, criticized the approach adopted by the court in Peens and Swart $v$ MKTV Beleggings Beherend BK [2003] 3 All SA 426 (T) on the premise that it limited the extent to which shareholders could exert influence over the payment of executive termination packages in terms of $s$ 227. See Luiz "Payment to Directors as Compensation for Loss of Office" 200517 SA Merc LJ 115 for a detailed analysis of this case.

64 Luiz 201325 SA Merc LJ 293. 
being decided exclusively by either the board or the remuneration committee instead.

Notwithstanding these shortcomings, some of the provisions in the Companies Act requiring shareholder approval of certain transactions constitute a positive development. For instance, the requirement that loans or other financial assistance given to directors as contemplated in sections 44 and 45 must be authorised by shareholders through a special resolution. ${ }^{65}$ The same requirement also applies where the company wishes to repurchase any of its shares from a director, a prescribed officer or a person related to such director or prescribed officer. ${ }^{66}$ These provisions help to limit potential abuse of company resources by directors and prescribed officers, while at the same time recognising the need for providing loans and other financial assistance to directors and prescribed officers in appropriate circumstances.

\section{The JSE listings requirements}

The adoption of share options and incentive schemes is subject to shareholder approval in terms of the JSE Listing Requirements. ${ }^{67}$ These requirements have a direct impact on the remuneration policies of listed companies in that the main elements of the schemes must be disclosed to the shareholders and cannot be altered without prior approval of the shareholders. ${ }^{68}$ Notably, such approval excludes all the votes attaching to equities securities owned or controlled by persons who are existing participants in the scheme. Thus, the disclosure and justification of essential elements of a share option or incentive schemes to the board of a listed company must be made before such schemes are put to shareholders' vote. It must be pointed out that, apart from cases where a company wishes to adopt share incentive schemes, there is no requirement under the JSE Listings Requirements for listed companies to obtain shareholder approval before issuing share options and incentive schemes to directors. Even in instances involving adoption of new share options and incentive schemes, shareholders are allowed to vote only on the rules and structures of the schemes, and have no say regarding the criteria for allocating shares or the amount of money involved. ${ }^{69}$

65 S 44(3)(a)(ii) of 71 of 2008 requires a special resolution of shareholders to authorise the board's decision to cause the company to provide financial assistance to any person for the subscription of options or any securities issued, or to be issued by the company or its related corporate entities. See also s 45(3)(a)(ii) which requires also a special resolution of shareholders to authorise the provision of loans or financial assistance to directors or prescribed officers.

66 S 48(8)(a) of 71 of 2008.

67 Paragraph 14.1 of Schedule 14 of the JSE Listings Requirements provides that the scheme must be approved by equity securities holders passing a resolution requiring a $75 \%$ majority of the votes cast in favour of such resolution at the general meeting to approve such resolution.

68 Paragraph 14.2 of Schedule 14 of the JSE Listings Requirements.

69 Crotty http://www.bdlive.co.za/opinion/2014/08/03/bigger-say-on-pay-is-only-a-starting-point (accessed 2015-06-26). 


\section{King III}

King III calls for passing of an advisory vote on the annual remuneration policy of a company by shareholders, and for the board to determine remuneration of executive directors in accordance with the remuneration policy put to shareholders' vote. ${ }^{70}$ The advisory vote is meant to increase the transparency and accountability of company boards to shareholders. ${ }^{71}$ It also encourages shareholders to engage actively with company boards and remuneration committees on matters relating to executive remuneration. Moreover, a negative vote on remuneration policy and the threat of reputational harm it creates, is likely to act as a restraint against excessive executive remuneration.

However, the provisions on shareholders' advisory vote in terms of King III have weaknesses of their own. First, the vote is not binding and, as such, may not have a significant and direct influence on the levels of executive remuneration. Without a binding shareholder resolution, there is no guarantee that shareholder concerns regarding excessive executive remuneration will be taken into account, and this is unlikely to lead to the desired outcomes. Secondly, compliance with King III as a market-based code of good practice is also voluntary, which may result in some companies choosing not to disclose their annual remuneration policies, or putting them to a shareholders' vote.

\section{Remuneration design}

The Companies $\mathrm{Act}^{72}$ has not done much in terms of regulating the design or structure of executive remuneration. Instead, it has avoided providing direct guidance regarding the quantum and form of executive remuneration, only doing so indirectly by imposing mandatory disclosure of certain aspects of executive remuneration and regulation of certain related party transactions as enunciated above. Remuneration design has thus been left to company boards and the market to regulate.

\section{Clawback policies}

It is notable that the South African regulatory framework does not provide for clawback policies. These policies enable companies to recover erroneously awarded variable pay incentives where appropriate. Clawbacks may play an important role, not only in preventing the diversion of company funds to excess or overpaid incentives, but also in aligning executive rewards with actual performance and long-term shareholder interests. ${ }^{73}$ It is therefore submitted that it would serve the interests of South Africa if these clauses were to be incorporated into the country's regulatory framework. Clawback

Principle 2.27 of King III.

Scholtz and Smit 2012 16(1) Southern African Business Review 23.

71 of 2008.

Fried and Shilon "Excess-Pay Clawbacks" 201136 The Journal of Corporation Law 721 735. 
policies have been mandated by legislation in the USA and Australia. South Africa can draw important lessons from the approaches in these two jurisdictions.

\section{Clawback policies in the USA}

In the USA, section 304 of the Sarbanes Oxley Act of $2002^{74}$ empowered the Securities Exchange Commission to recover from company CEOs and CFOs any incentive compensation and profits from stock sales following accounting restatements resulting from material noncompliance by the issuer with any financial reporting requirement under the securities laws due to misconduct. The scope of this provision was severely limited since it applied only to accounting misstatements where there had been misconduct. In addition, only incentive compensation received within the 12-month period following the misleading financial statement could be recouped from the CEOs and CFOs.

In 2010 the Dodd-Frank Wall Street Reform and Consumer Protection Act $^{75}$ amended the Securities Exchange Act of $1934^{76}$ by inserting a new section 10D, requiring the Securities Exchange Commission to ensure that all listed public companies disclose their policy on clawbacks. ${ }^{77}$ In terms of section $10 \mathrm{D}(b)(2)$, the policy on clawbacks must prescribe that, if the company is required to prepare an accounting restatement as a result of its material noncompliance with financial reporting requirements under the securities laws, such a company must recover incentive-based compensation from current or former executive officers received during the 3-year period preceding the date on which the company has been required to prepare an accounting restatement.

Dodd-Frank is an improvement compared to the SOX in that it has widened the circumstances under which clawbacks will apply. In addition, misconduct is no longer a requirement for triggering the operation of clawbacks under Dodd-Frank. The category of individuals on whom clawbacks will apply and the period during which the clawbacks will apply have also been extended. Furthermore, under Dodd-Frank it is the company that is required to recover the "excess" payment.

\section{Clawback policies in Australia}

In Australia, the Federal Government released a discussion paper in December 2010, calling for the clawing back of executive remuneration in instances where financial statements have turned out to have been materially misstated. ${ }^{78}$ The Government was responding to the community's concerns about excessive and inappropriate remuneration practices. The majority of the submissions made to the discussion paper, however,

\footnotetext{
Hereinafter referred to as "SOX".

Hereinafter referred to as "Dodd-Frank".

15 U.S.C. 78 a et seq.

See s 954 of the Dodd-Frank Wall Street Reform and Consumer Protection Act of 2010.

78 See Australian Government Discussion Paper The Clawback of Executive Remuneration where Financial Statements are Materially Misstated 2010.
} 
appeared to be opposed to the idea of enshrining clawbacks in legislation and, instead, preferred leaving it to the discretion of company boards or the Australian Stock Exchange (ASX) Governance Council's principles to regulate them. ${ }^{79}$ The reason cited for opposing the use of legislation was that it is rigid and offers only a one-size-fits-all solution, not suitable for all companies.

When the Australian Federal Government finally decided on the appropriate approach to follow concerning clawbacks, it was reflected in the exposure draft of the Corporations Legislation Amendment (Remuneration Disclosures and Other Measures) Bill 2012, which is yet to be enacted into legislation. The Bill proposes to amend section $300 \mathrm{~A}(1)$ of the Corporations Act 2001 by inserting a new requirement. In terms of the requirement, if a listed company becomes aware during the financial year of a material misstatement or omission in the financial statements in relation to the company in any of the previous 3 financial years, it must disclose in its remuneration report, for each of the key management personnel (KMP), the "details of any reduction, repayment, or other alteration of the person's remuneration made, or to be made, because of the misstatement or omission". ${ }^{81}$ If a reduction, repayment or alteration of the person's remuneration has not been made, and will not be made, then an "explanation of why" must be disclosed. ${ }^{82}$ The Australian Federal Government has thus adopted a "comply-or-explain" approach.

Under the proposed law, clawbacks will, therefore, be applicable to listed companies that have become aware, during the financial year, of material misstatements in their three previous financial statements. The obligation imposed on listed companies to disclose whether overpayments, made to their executives because of such misstatement, had been or would be recovered from the individuals concerned, is obviously meant to coerce listed companies into incorporating clawbacks into their executive remuneration arrangements. Notably, the disclosure requirement kicks in only once a material misstatement or omission in the financial statements comes to the attention of the listed company.

\section{Proposals for South Africa}

South Africa would do well to follow the example of the US and Australia by adopting clawback policies. To this end, it is submitted that the country

79 See Kovačević "Executive Remuneration Developments in Australia: Responses and Reactions" 201223 The Economic and Labour Relations Review 99107.

80 Chartered Secretaries Australia Submission to Federal Treasury on Discussion Paper "The Clawback of Executive Remuneration where Financial Statements are Materially Misstated" 2011. Chartered Secretaries Australia (CSA) applauded publication of the discussion paper, but expressed reservations about incorporating clawbacks into legislation. In its submission, the Institute of Chartered Accountants reiterated CSA's position that should the Government decide to proceed with implementing the clawback policy, it should allow companies to design appropriate policies for their remuneration frameworks.

81 See $\mathrm{s} 9$ of Schedule 1 of the of the Corporations Legislation Amendment (Remuneration Disclosures and Other Measures) Bill 2012.

82 Ibid. 
should include a requirement for companies to adopt and disclose clawback policies in the Companies Act 2008. This is because provisions of the Companies Act are mandatory and apply to all companies. This is in contrast to the JSE Listings Requirements which are only binding on listed companies and the recommendations of King III whose implementation is predominantly dependent on the directors' discretion. In order to avoid the rigidity that is often associated with prescriptive legislative provisions, it is submitted that a "comply-or-explain" approach proposed for Australia be adopted in South Africa. It is submitted that this approach will allow for flexibility needed to cater for different companies.

The proposed clawbacks should apply to all performance-based remuneration awarded to current and former company directors, as well as to prescribed officers. In the USA and Australia, clawbacks are triggered only by financial restatements resulting from a company's material noncompliance with financial reporting requirements. This has been criticised for severely restricting the circumstances under which overpaid remuneration can be recovered through clawbacks. ${ }^{83}$ Suggestions have been made that companies should be allowed to recover overpaid remuneration regardless of whether or not a restatement is required. ${ }^{84}$

Lastly, focusing solely on financial metrics, would restrict the operation of clawbacks since companies may use non-financial metrics to determine performance-based remuneration. ${ }^{85}$ It is, therefore, submitted that the reach of the clawback provisions should cover instances where performancebased incentives were awarded, paid or vested on the basis of inaccurate financial information, inaccurate performance criteria, poor risk management, fraud and improper conduct. Such criteria should apply regardless of whether or not there has been any misconduct on the part of the director or executive officer involved.

\section{CONCLUSION}

Although efforts have been made to regulate executive pay in South Africa, it is quite clear from the preceding discussion that these efforts have fallen short so far. This is nowhere more evident than in the continued failure by most local companies to reform their approach to executive remuneration. For the most part, there is still no alignment between the progressive recommendations made in the existing codes of good practice and the current companies legislation, which has served to give the companies a leeway to ignore the calls for change.

While external intervention may not always be desirable in determining appropriate remuneration for company executives due to the complex nature of companies, the differences in their operations and size, as well as their needs to retain scarce skills, legislative intervention can be helpful in ensuring that companies do not exceed reasonable limits in setting their remuneration policies and packages. Legislative measures can help to

\footnotetext{
Fried and Shilon 201136 The Journal of Corporation Law 748

Ibid.

Ibid.
} 
compel companies to subject their executive remuneration and termination packages to shareholder approval through a binding vote. It is submitted that shareholder approval should also be required before companies issue share options to directors.

Furthermore, the companies legislation should oblige companies to make clear and effective disclosure of their remuneration policy so as to enable the shareholders and stakeholders to make an informed evaluation. The companies legislation should further require companies to adopt and disclose their clawback policies in order to facilitate recovery of excess payments and benefits obtained by directors and senior executives in a variety of circumstances, including through fraud, withholding of relevant information, or other improper conduct. Clawbacks should also be used in cases of poor risk management, short-termism, poor performance and failure to meet the performance requirements on the part of company executives. As pointed out above, the "comply-or-explain" approach proposed for Australia is the better approach than a one-size-fits-all approach since it allows for flexibility in catering for different companies and situations. 